\title{
Standards of Proof and Civil Litigation: A Game-Theoretic Analysis
}

\author{
${ }^{1}$ Department of Economics, University of Modena and Reggio Emilia, Modena, Italy, E-mail: barbara.luppi@unimore.it \\ ${ }^{2}$ Department of Business and Politics, Copenhagen Business School, Frederiksberg, Denmark, E-mail: agu.dbp@cbs.dk \\ ${ }^{3}$ Department of EconomicsUniversity of Minnesota, Minnesota, USA, School of Law and University of Bologna, Bolognaltaly, \\ E-mail: parisi@umn.edu
}

\begin{abstract}
:
In litigation models, the parties' probability to succeed in a lawsuit hinge upon the merits of the parties' claims and their litigation efforts. In this paper we extend this framework to consider an important procedural aspect of the legal system: the standard of proof. We recast the conventional litigation model to consider how alternative standards of proof affect litigation choices. We analyze the interrelation between different standards of proof, the effectiveness of the parties' efforts, and the merits of the case. We study how these factors jointly affect the parties' litigation expenditures, the selection of cases brought to the courts, pretrial bargain solutions and preemptive strategies. Our results show that standards of proof are not only instrumental to balancing the competing goals of access to justice and judicial truth-finding, but they also play a critical role in affecting parties' litigation investments and settlement choices, and in sorting the mix of cases that will actually be filed and defended in courts. The understanding of the sorting effect of standards of proof sheds light on their role as a policy instrument in civil litigation.
\end{abstract}

Keywords: litigation, standard of proof, litigation contest functions

JEL classification: C72, D72, D8, K10, K41

DOI: 10.1515/bejte-2017-0005

\section{Introduction}

In the law and economics literature, litigation contest functions have been extensively utilized to study the incentives of parties involved in litigation. ${ }^{1}$ Similar to an unproductive competition contest, parties involved in litigation expend costly efforts to win a case, and a sizeable share of the value of the case is dissipated in litigation expenditures (Congleton, Hillman, and Konrad 1980, p. 41). Tullock's (1967 and 1980) and Krueger's (1974) models have been used to study the plaintiff's decision to file a case, the defendant's choice to defend it, and the private investments in legal expenditures. Among others, Daughety and Reinganum (2003), Farmer and Pecorino (1999 and 2013a) , Guerra, Luppi, and Parisi (2018), Hillman and Katz (1988), Hirshleifer (1989), Hirshleifer and Osborne (2001), Parisi (2002), and Tullock (1975) applied this framework to analyze the litigation process in the context of both civil and criminal cases.

The conventional models applied to litigation assume the parties' probability of success in a lawsuit depend upon two main factors: the parties' respective merits in the case and their litigation efforts (Katz 1988; Hirshleifer 1989; Farmer and Pecorino 1999; Hirshleifer and Osborne 2001). In a typical lawsuit, however, the judge assesses the merits and the relative strength of the evidence presented by the parties. Standards of proof specify the strength of the evidence which a party must present in a lawsuit. Thus, the plaintiff's decision to bring suit in the first place and the defendant's choice to defend it hinge upon the relationship between the objective merits of their claims and the applicable standard of proof. While the previous rent-seeking models applied to litigation contexts left unexplored such interaction, ${ }^{2}$ a proper and complete modeling of the litigation context should include standards of proof. This paper contributes to the existing literature, bringing standards of proof as an institutional variable into the analysis.

Standards of proof are an institutional variable determined by procedural rules: they affect the difficulty and likelihood of proving a legal claim in a court of justice, specifying how likely a legal or factual claim is to be grounded for relief to be granted. ${ }^{3}$ Common-law and civil-law systems differ in setting standards of proof in civil disputes (Demougin and Fluet 2005). Further, the standards of proof may vary in the course of a legal proceeding with relatively low standards being adopted to scrutinize the admissibility of a case and in granting 
temporary judicial measures for the protection of a claim, and higher standards needed to be met for satisfying a legal claim. In common law, the most commonly used standard of proof requires plaintiffs to prove their claim by the so-called "preponderance of evidence" standard (or "balance of probabilities"), which means "to prove that something is more likely so than not so". This is generally understood as implying a 50\% threshold degree of certainty. ${ }^{4}$

Both lower and higher standards are also used for certain categories of legal claims. Lower than 50\% standards are frequently seen in early phases of legal proceedings, where preliminary injunctions are granted to claimants when irreparable harm would ensue in the absence of judicial intervention. These lower standards are observed when temporary or urgent remedies are sought, such as in harassment cases, restraining orders, and other measures granting temporary relief or staying the force of a judgment pending other proceedings. ${ }^{5}$ In granting these preliminary remedies, courts have adopted different standards of proof depending on the type of cases, many of which fall below the 50\% (more likely than not) standard. The standard of "reasonable proof" is one of the lowest standard adopted by courts to provide a remedy. Often times this standard can be satisfied by a unilateral declaration under penalty of perjury. Under this standard, an injunctive relief can be granted even where the only evidence is the unilateral statement of the petitioner. As a case proceeds toward final adjudication, higher standards of proof are adopted.

Higher than 50\% evidence standards are also often adopted in civil litigation. For example, in some civil cases, more stringent standards are applied and one must adduce "clear and convincing" proof. This standard is applied when settling cases involving withdrawal of life support in comatose patients, child custody, involuntary commitment, or in some administrative disciplinary proceedings for attorneys, physicians or other medical professionals. ${ }^{6}{ }^{7}$ Civil-law courts apply a higher degree of certainty than the common-law preponderance standard, and do not differentiate between civil and criminal cases with regard to the standard of proof (Engel 2008). ${ }^{8}$ The civil-law standard of proof is always the full conviction of the judge and it is commonly labeled as intime conviction or conviction raisonnée, that is an inner, deep-seated conviction of the judge (Clermont and Sherwin 2002). ${ }^{9}$ This difference in procedural standards of proof implies that two identical cases, subject to the same substantive law might lead to very different outcomes in the two legal systems: a plaintiff who wins in a common law jurisdiction could lose in a civil law jurisdiction, notwithstanding the similarity of the case and of the applicable law. It is worth remarking that, certainly in German and Swiss law, there are exceptions to the standard of full conviction in civil cases, namely for allegations that are notoriously difficult to prove, such as causality in medical malpractice or the theft of an insured item to be proven by the policy holder (Kaye 1983). ${ }^{10}$ In such situations, a lower standard of "prima facie evidence" is generally applied, which is satisfied if the factual allegations supporting the claim are more probably true than not. Despite the clearly intended intermediate position of this standard, longstanding legal discussions on the standard's application have revealed uncertainty about standards of proof in general (Kagehiro and Stanton 1985). ${ }^{11}$

Previous contributions on standards of proof showed that, either in civil or criminal contexts optimality entails a tradeoff between error costs and litigation expenditures (Rubinfeld and Sappington 1987; Miceli 1990; Davis 1994; Sanchirico 1997). Generally speaking, in common law jurisdictions the preponderance standard is justified on the ground of minimizing the expected cost of legal errors. Unlike criminal cases, in civil cases a claim that is erroneously decided in favor of the plaintiff is generally just as undesirable as a claim that is erroneously decided in favor of the defendant (e.g., Addington v. Texas; Santosky v. Kramer; Grogan v. Garner). ${ }^{12}$ As a consequence, standards of proof in civil cases avoid strong biases in favor of plaintiffs or defendants. ${ }^{13}$ In yet other cases legal systems utilize standards of proof in an attempt to minimize the expected cost of judicial errors. These standards fall between the "beyond a reasonable doubt" and the "preponderance of evidence" standards. ${ }^{14}$

The fact that standards of proof adopted by civil law jurisdictions are all higher than the preponderance standard adopted by common law jurisdictions follows from the premise that even in a purely civil case there is a presumption of the defendant's innocence. In an attempt to explain the rationale for such different evidence standards in common-law and civil-law courts, Clermont and Sherwin (2002) proposed a legitimacy-versuserror-minimization interpretation: the divergence stands "between the error minimizing strategy pursued in common law and the legitimacy-seeking strategy of civil law" ${ }^{15}$ In this respect, legitimacy is obtained by requiring very convincing evidence to rule in favor of the party with the burden of proof. Clermont and Sherwin (2002) also noted that while the common-law standard is well articulated, invariant and unambiguous in its applications, "civil law does not enunciate its civil standard too expressly, loudly, or frequently" (Clermont and Sherwin 2002, 245). Patent law can serve as an example. Section 282 of the Patent Act adopted in 1952, expressly states that patents are to be presumed valid, but does not specify the standard of proof (Lemley and Shapiro 2005; Schwartz and Seaman 2013). ${ }^{16}$ This is a clear case in which the law explicitly specifies the burden of proof - meant as burden of producing evidence-, but includes no express articulation of the standard of proof. For this reason, patent law may serve as a good theoretical and empirical ground to analyze variations 
in the standard of proof. In Section 2.5.2, we shall further explore the effect of letting the burden of establishing invalidity of a patent or any claim thereof resting on the party asserting such invalidity.

Given the extensive range of possible standards of proof applicable in civil cases and the ambiguous definition of the standard of proof in civil-law courts, the question arising is whether some civil standards perform better than others and with respect to what objective. Despite the perceived importance of standards of proof in litigation (Hay 1997; Hay and Spier 1997; Kaplow 2012), there has not been a theoretical study analyzing the effects of alternative standards of proof on parties' litigation choices, particularly in civil litigation. The impact of changing the standard of proof on parties' litigation choices in civil cases has not been explored. For example, in the area of patent law Doug Lichtman and Mark Lemley admitted that the legal community "know[s] far less than [it] should about how presumptions affect litigation decisions." (Lichtman and Lemley 2007). Some previous contributions showed that the choice of the standard of proof should be based on the twofold role of evidence: truth-finding and minimization of the cost of judicial errors (e.g., Davis 1994; Cooter and Emons 2003; De Mot 2013; Demougin and Fluet 2006, 2005). ${ }^{17}$ In this paper we show that in addition to these functions, standards of proof play additional roles in civil litigation. We identify a previously unexplored sorting effect, showing that standards of proof affect the parties' incentives to participate and expend in litigation, changing the mix of cases that are brought to the court system. We suggest that this sorting effect should be taken into consideration when setting legal standards of proof. Courts can use standards to limit the costs of resolving a dispute. Moreover, the standard of proof can serve as a preemptive strategy in a pretrial settlement and as a mechanism inducing split-award solutions. ${ }^{18}$

The paper is structured as follows. Section 2 recasts the conventional litigation model to analyze how alternative standards of proof affect parties' litigation choices. We consider how different standards of proof, the exogenous merits of the case, and the effectiveness of legal expenditures jointly affect the parties' litigation incentives and aggregate litigation expenditures. Specifically, Nash equilibrium expenditures in litigation are studied in Section 2.1, parties' participation constraints are analyzed in Section 2.2, and the resulting dissipation through litigation is considered in Section 2.4. In Section 2.5 we analyze different settlement options, considering not only parties' preemptive litigation expenditures (Section 2.5.1), but also the possibility of preemptive evidence standards (Section 2.5.2) and split-award regimes (Section 2.5.3). Section 3 derives policy implications and Section 4 suggests possible extensions of the analysis.

\section{The Model}

Following Farmer and Pecorino (1999), Hirshleifer and Osborne (2001), and Katz (1988), we consider the following litigation context. A risk-neutral plaintiff decides whether or not to file suit costlessly. If a suit is not filed, the game ends, whereas if the suit is filed, the case proceeds. In this latter case, a risk-neutral defendant decides whether or not to defend the case. If he does not defend the case, he pays the plaintiff the default judgment $J$, and the game ends. If he decides to defend the case, the case proceeds to trial.

At trial, the plaintiff and the defendant invest in litigation effort $X$ and $Y$ respectively to maximize their own expected returns. The probability that a party prevails in litigation depends upon the parties' objective merits of the case, their legal expenditures and the standard of proof. The greater one party's litigation investment compared to the opponent's, the more likely it is for that party to prevail in litigation. If the plaintiff prevails, the defendant pays the amount $J$. We assume identical stakes, except for the sign: the plaintiff gains $(J)$ what the defendant loses $(-J)$. Legal expenditures borne by the parties are allocated according to the American rule, under which each party pays his or her own legal expenses, regardless of who prevails at trial.

Let $M$ represents the exogenous merits of the case, which favors the plaintiff when $M>0$, the defendant when $M<0$, and neither party when $M=0$. The true degree of fault $M$ is known by both litigants but it is not known by the court, whose decision is based upon the parties' respective litigation efforts. Let $S \in(0,1)$ denote the standard of proof, which lies between 0 and 1 . By considering this interval, we can analyze different values of standards of proof, ranging from the lowest standards (e.g., reasonable grounds for suspicion), to the highest standard (e.g., the beyond a reasonable doubt). For purely illustrative purposes, in our simulations cases that follow a balanced evidentiary standard such as the "more likely than not" standard are represented by $S=0.5$; cases that follow the "clear and convincing" standard are represented by $S=0.75$; and cases that follow the "beyond a reasonable doubt" standard are represented by $S=0.9$. To capture the entire spectrum of evidence standards, we let the standard of proof $S$ take values below the conventional "preponderance" standard. This allows us to analyze other, not frequently studied standards of proof such as "reasonable proof," and "probable cause" standards, generally used in temporary injunctive relief cases. ${ }^{19}$ In our simulations, cases that adopt these lower standards are represented by $S=0.25$. Considering a wider range of possible standards of proof 
allows us to discuss when (i.e., under which conditions) standards lower than preponderance are possible and should be optimally applied.

Let $\alpha<0$ represent the effectiveness of legal expenditures (technology parameter). Following the conventional litigation model (Hillman and Katz 1988; Hirshleifer 1989; Farmer and Pecorino 1999), if $\alpha<1$ there are decreasing returns to scale in the production of legal arguments and if $\alpha>1$ there are increasing returns to scale in the production of legal arguments. If $\alpha=1$, returns to scale are constant. As in Farmer and Pecorino (1999), we assume symmetric effectiveness of legal expenditures between the parties. ${ }^{20}$

As standard in the literature, we assume the parties to have common knowledge of all the relevant functions and parameters, including the actual level of fault, the stakes, the costs of trial, and the structural relationships set in the model.

The probability that the plaintiff wins the case takes the Tullock's $(1967,1980)$ logit-form contest success function with bias applied to litigation, as in Hillman and Katz (1988), Farmer and Pecorino (1999), and Hirshleifer and Osborne (2001): ${ }^{21}$

$$
P=\frac{X^{\alpha}}{X^{\alpha}+\theta(M, S) Y^{\alpha}}
$$

with

$$
\theta(M, S)=e^{\frac{1}{1-S}-\frac{M}{S}}
$$

The probability function eq. (1) extends Farmer and Pecorino's (1999) litigation success function $\left(P_{F P}=\right.$ $\left.X^{\alpha} /\left(X^{\alpha}+e^{-M} Y^{\alpha}\right)\right)$ to consider $\theta(M, S)$ which captures the countervailing effects of the merits of the case and the standard of proof on the parties' returns to litigation effort. The function $\theta-$-which is convex and positive-is decreasing in $M$ and increasing in $S$. By construction, the standard of proof has diametrically opposed effects on the plaintiff's and the defendant's winning probabilities. The asymmetric impact of $S$ on the defendant's winning probability is reflected in $\theta$ through the factor $\frac{1}{1-S}$. For any given merit of the case, the higher the standard of proof, the more difficult it is for the plaintiff to satisfy it (this effect is captured by the ratio $-\frac{M}{S}$ ), while the easier it is for the defendant to win the case (this effect is captured by the ratio $\frac{1}{1-S}$ ). ${ }^{22}$

This setup leads the plaintiff's probability of success to increase with the merits of his case, $M$, and to decrease when standards of proof, $S$, are adopted. ${ }^{23}$

Prior literature analyzed countervailing incentives in litigation models. Among others, Deffains, Demougin, and Desrieux (2017) analyzed countervailing incentives in the choice between alternative dispute resolution and court litigation. They found that litigation shifts the cost function upward but at the same time it may reduce parties' willingness to engage in a legal contest: in equilibrium contestants may spend less under litigation rather than under alternative dispute resolution.

From a formal perspective, our framework follows the well-known Tullock rent-seeking game. As standard in the literature (Farmer and Pecorino 1999), we formulate the winning probabilities in terms of the parties' expenditures and assume linear cost functions in litigation expenditures. This general framework allows us to analyze both the equilibrium behavior and participation constraints. ${ }^{24}$

\subsection{Litigation Efforts and Equilibrium Behavior}

The plaintiff chooses $X$ to maximize her expected award at trial. Given that the outcome of a trial will be an award of $J$ with probability $P$ defined in eq. (1), the plaintiff's objective function is given by:

$$
\max _{X}\left(\frac{X^{\alpha}}{X^{\alpha}+\theta(M, S) Y^{\alpha}}\right) J-X
$$

The first-order condition for this problem implies

$$
\theta(M, S) Y^{\alpha} X^{\alpha-1} \alpha J=\left(X^{\alpha}+\theta(M, S) Y^{\alpha}\right)^{2}
$$

Similarly, the defendant chooses $Y$ to minimize his expected liability. The defendant's objective function can thus be written as:

$$
\max _{Y}-\left(\frac{X^{\alpha}}{X^{\alpha}+\theta(M, S) Y^{\alpha}}\right) J-Y
$$

The first-order condition for this problem implies

$$
\theta(M, S) X^{\alpha} Y^{\alpha-1} \alpha J=\left(X^{\alpha}+\theta(M, S) Y^{\alpha}\right)^{2}
$$


Equations (4) and (6) are solved simultaneously to derive the equilibrium expenditures $X^{*}=Y^{*}$ :

$$
X^{*}=Y^{*}=\frac{\theta(M, S) \alpha J}{(1+\theta(M, S))^{2}}
$$

From eq. (1), the resulting equilibrium probability that the plaintiff prevails (plaintiff's win probability, hereinafter) is

$$
P^{*}=\frac{1}{1+\theta(M, S)}
$$

where $\theta$ is defined in eq. (2). In equilibrium, the plaintiff's win probability eq. (8) is affected by the interaction between the objective merit of the case and the standard of proof, as shown in Figure 1.

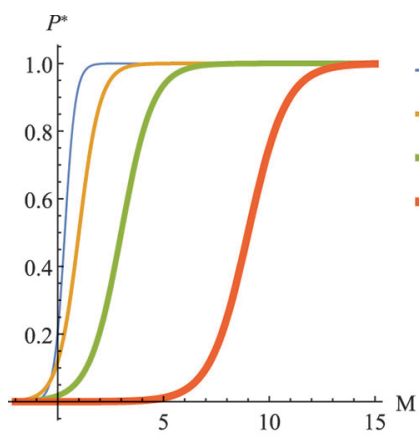

(a)

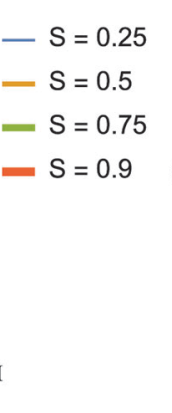

$-\mathrm{S}=0.5$

- $\mathrm{S}=0.75$

$-\mathrm{S}=0.9$

(1)

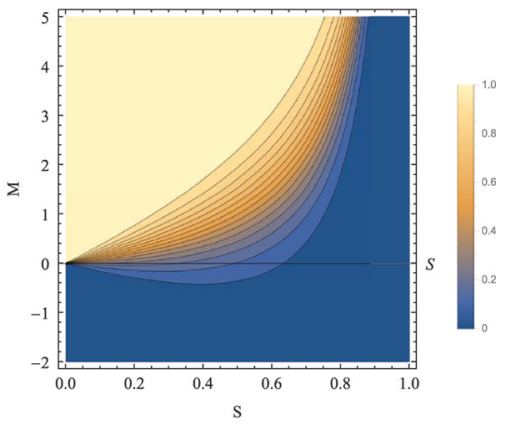

(b)

Figure 1: Plaintiff's win probability in equilibrium, $P^{*}$.

Figure 1 clearly shows that the plaintiff's win probability in equilibrium increases with the objective merit of the case and decreases with the standard of proof. It is interesting to note that frivolous claims can succeed especially in the presence of low standards of proof. See, for example, the values under a preponderance standard, $P^{*}=0.018$ if $S=0.5$ and $M=-1$. In these cases, even if the plaintiff's win probability at trial remains very low, a settlement range always exists and defendant may agree to settle a case notwithstanding its non-meritorious basis. By contrast, even in high-merit cases, the plaintiff's win probability remains low if the standard of proof is set high (e.g., $P^{*}=0.25$ if $M=8$ and $S=0.9$ ).

The interplay between standards of proof and objective merits of a case and its effect on the plaintiff's win probability is interesting at this point, in light of the potential decision-making errors. As shown in Figure 1, when the objective merit of the case strongly favors the plaintiff, setting a relatively high standard of proof (i.e., $S \geq 0.9$ ) might increase the likelihood of excluding liability for a negligent defendant, notwithstanding his manifest fault. On the opposite, when the objective merit of the case favors the defendant, setting a relatively low standard of proof (i.e., $S \leq 0.6$ ) might increase the likelihood of imposing liability on a diligent defendant, notwithstanding his careful behavior. ${ }^{25}$

Let us now consider the parties' efforts in equilibrium. From eq. (7), for any given standard of proof and merit, more resources will be spent when litigation expenditures are more effective. The equilibrium effort increases up to $\theta(M, S)=1$ and decreases thereafter. In our specification, $\theta(M, S)=1$ when $M=\frac{S}{1-S}$ or $S=\frac{M}{1+M}$. Given equal merits, the outcome at trial should depend not only upon the litigation effort --as, Hirshleifer and Osborne's (2001) specification would predict-- but also upon the standard of proof. For any given value of the objective merit, standards of proof that depart from preponderance of evidence $(S=0.5)$ create an advantage of one party over the other. Interestingly, this advantage affects the parties' success probabilities, but does not affect the parties' relative investments in litigation. By comparing eqs. (4) and (6), we find that parties' investments in litigation are symmetrical under any value of $S$.

Similarly, parties' investments in litigation are symmetrical under any value of $M$ (Tullock 1980; Farmer and Pecorino 1999; Hirshleifer and Osborne 2001; Deffains, Demougin, and Desrieux 2017).

Values of $M \neq 0$ imply that one party's claim is more meritorious than the other's. The party with a more meritorious claim has an advantage over the other in litigation. Notwithstanding this asymmetry, parties will invest an equal amount of effort in litigation. That is, changes in the parties' respective merits do not affect their investments in litigation. ${ }^{26}$ A party who has a meritorious claim will invest as much as his opponent, who is defending a less meritorious counterclaim.

The merits of the case, however, affect the magnitude of the parties' investments in litigation. That is, parties will behave symmetrically but their litigation expenditures will be (equally) affected by changes in $M$. The interaction between the values of $M$ and $S$ becomes interesting at this point, as pointed out in the following results. 


\section{Result 2.1}

[Standards of Proof and Individual Litigation Expenditures]. When the standard of proof is set high, highest expenditures are observed for high-merit cases. Conversely, when the standard of proof is set low, highest expenditures are observed for low-merit cases.

This result follows straightforwardly from the optimization problem. Let $\theta^{*}$ denote the $\theta$ which maximizes expenditure. It follows that $\theta=\theta^{*}$ defines the function $S(M)=M /(1+M)$, which explains Result 2.1.

Figure 2 shows how the individual equilibrium effort eq. (7) varies with the relevant parameters of the model.

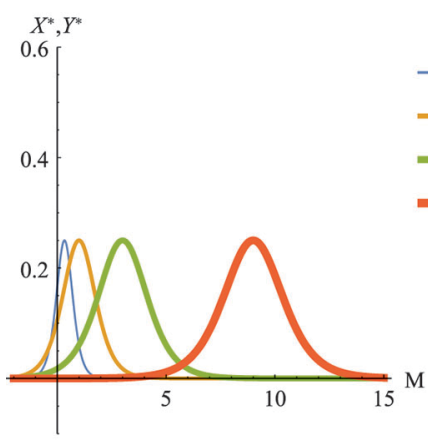

(a)

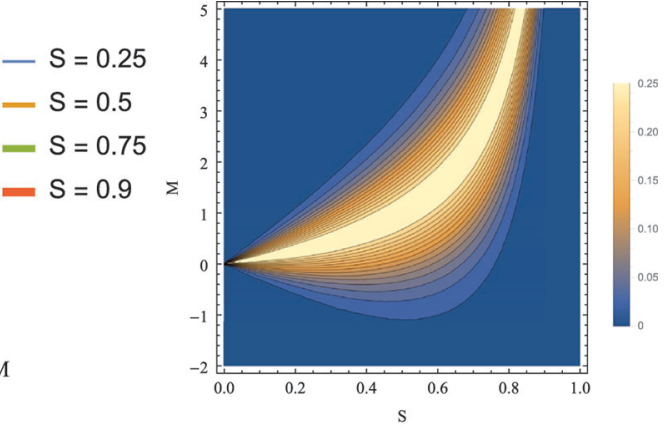

(b)

Figure 2: Individual equilibrium effort, $X^{*}, Y^{*}(\alpha, J=1)$.

Figure 2a plots individual equilibrium effort as a function of the merits of the case under four different representative standards of proof. The contour-plot $2 b$ shows the values of the individual equilibrium effort under different combinations of the evidence standards and the objective merits of the case. It can be easily noticed that individual equilibrium effort peaks at 0.25 when standard of proof and objective merits are of similar magnitude (lighter area in the contour-plot 2b). For example, for a standard of proof set at $S=0.9$, highest expenditures are observed when the merit of the plaintiff's case is relatively large. Conversely, for a standard of proof set at $S=0.5$, highest expenditures are observed for low-merit cases. It is interesting to note that the range of positive equilibrium effort is larger for values of the standard of proof that range around the preponderance standard, i.e., when $S$ ranges around 0.5 .

Given the symmetry of the resulting efforts despite asymmetries in the respective merits of the case, aggregate effort will follow a similar pattern of individual efforts (Figure 3). Contrary to the traditional results of Gradstein (1995) and Farmer and Pecorino (1999), aggregate expenditures peak at different values of $M$ (and not exactly at $M=0$ ), depending on the standard of proof. As for Result 2.1, this result follows straightforwardly from the first-order derivatives of the aggregate equilibrium effort with respect to $S$, which yields to $S(M)=M /(1+M)$.

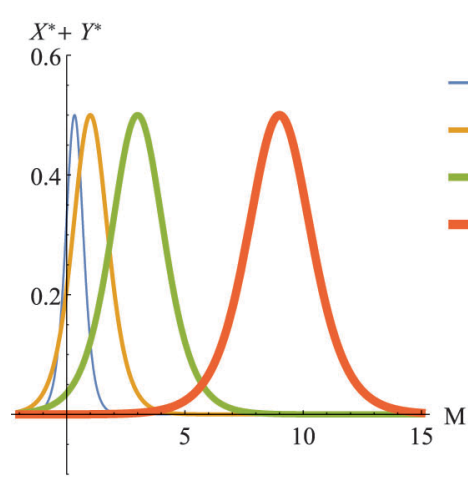

(a)

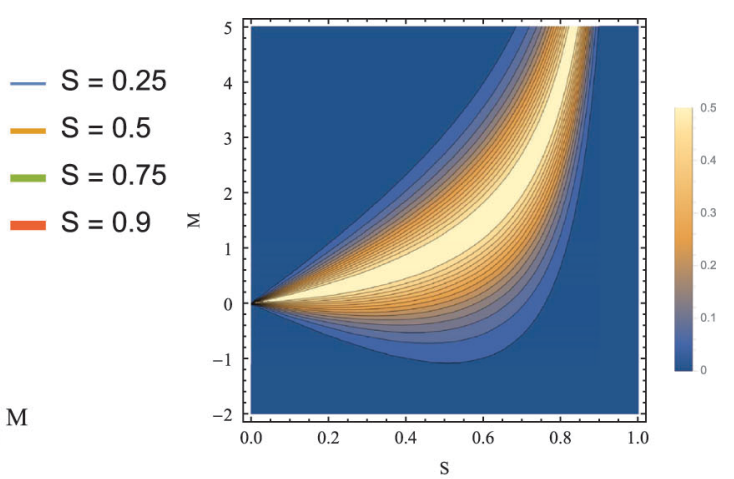

(b)

Figure 3: Aggregate equilibrium effort $(\alpha, J=1)$.

Gradstein (1995) and Farmer and Pecorino (1999) found that the total spending by two litigants is the highest when $M=0$, that is the parties' claims have comparable objective merits. We find that the highest aggregate effort depends upon the interaction between the objective merit of the case and the evidence standard. When the standard of proof is high, parties will actually litigate more vigorously cases that have strong merits in favor of plaintiffs. As the standard of proof is lowered, the cases that are actually litigated most vigorously are the less meritorious ones. 
The maximal values of individual (aggregate) effort equal 0.25 (.5). This is consistent with the dissipation levels observed in Tullock's (1980) contest success function when parties have constant returns to effort, $\alpha=1$. However, the standard dissipation levels in which the parties' total expenditures equal half of the value of the prize (Tullock 1980) are only observed for a narrow range of values in our litigation contest. In Figure $3 \mathrm{~b}$ it is possible to detect the pair of values of merits and standards of proof which generates the standard aggregate dissipation of $J / 2$ (the lightest area in the contour-plot 3b). As we depart from this specific combination of values, aggregate expenditures decrease quite rapidly. As it will be discussed in Section 3, standards of evidence can therefore be used as instruments for mitigating parties' excessive investments in litigation.

As it will be discussed in Section 3, these results provide valuable insights for the institutional design of evidence rules. It is interesting to observe that for the region of standard of proof $S \in[.5,1)$ highest expenditures are observed when the plaintiff's claim is relatively stronger than defendant's defense. By contrast, frivolous claims, $M<0$, are characterized by highest aggregate expenditures when standards of proof are set below the preponderance standard, such as the case of harassment suits, temporary restrain order and temporary injunctive relief in general.

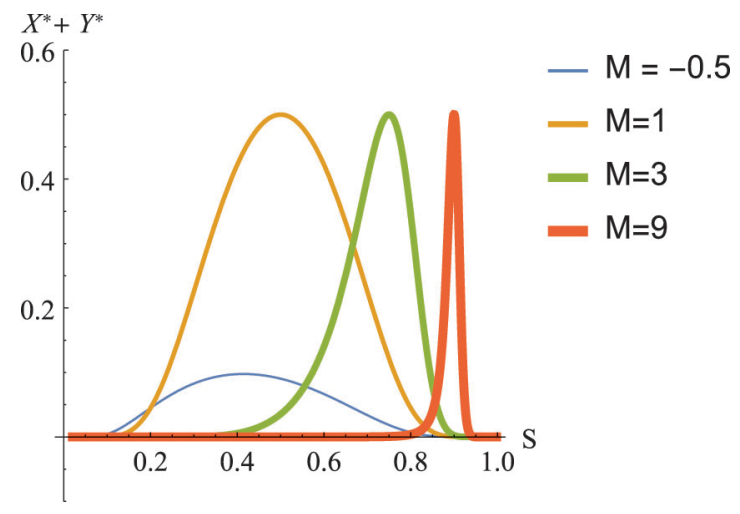

Figure 4: Aggregate effort (with $\alpha, J=1$ ).

Figure 4 plots aggregate expenditures in litigation as a function of the standard of proof under four representative values of the merit of the case. Figure 4 shows that frivolous claims brought by plaintiffs would not generate very high expenditures in litigation, except for the limited situations where standards lower than 0.5 are adopted.

\section{Result 2.2}

[Standards of Proof and Aggregate Litigation Expenditures]. The highest aggregate expenditures are determined by the combined choice of standards of proof and merits of the case, not necessarily in cases that have similar objective merits $(M \approx 0$, as in p.137 Katz 1988).

Results 2.1 and 2.2 suggest that, in order to minimize expenditures in litigation, highest standards of proof are warranted for low-merit cases and lower standards for high-merit cases.

Let us consider for example patent law, where patents are presumed valid. In 2011 the U.S. Supreme Court directly addressed the issue on how high the standard of proof should be for proving patent invalidity in litigation. In Microsoft Corp. v. i4i Ltd. P' ship, ${ }^{27}$ the Court examined whether Section 282 of the Patent Act required clear and convincing evidence to overcome a patent's presumption of validity. By rejecting Microsoft Corporation's claim that the default standard of proof in civil cases --preponderance of the evidence-- should apply, the Court agreed with i4i Ltd.'s argument that the phrase "presumed valid" had a settled meaning when the Patent Act was adopted in 1952, that required the patent challenger to satisfy this heightened standard of proof by clear and convincing evidence. In a brief filed in the i4i case, Apple and Intel --which both own large patent portfolios and appear as frequent defendants in infringement litigation-- argued that the clear and convincing evidence standard "has a compelling effect on jurors" and "insulate[s] weak patents from invalidity verdicts." (Schwartz and Seaman 2013).

Furthermore, we find that low-merit claims can be characterized by high aggregate expenditures, only under standards of proof $S<0.5$. This explains the situations in which legal systems set the standard of proof below the $50 \%$ threshold of the preponderance of evidence standard. These situations are observed when temporary or urgent remedies are sought, such as in orders for protection, harassment restraining orders, and other measures granting temporary relief or staying the force of a judgment pending other proceedings. 


\subsection{Participation Constraints}

As incentives to invest in litigation and equilibrium efforts change, so do the parties' incentives to participate in litigation. Higher equilibrium efforts mean more expensive - and less attractive - litigation. We can use the set-up introduced in Section 2 to verify litigants' participation constraints. We will show that, when $\alpha>1$, the solution in eq. (7) may not constitute an equilibrium as one or both players' participation constraint is violated.

In a litigation contest, participation constraints are interpreted as the parties' willingness to bring or to defend a claim. A plaintiff's failure to participate implies that the plaintiff foregoes his claim and chooses not to file an action against his defendant. When a defendant's participation constraint is not satisfied, the defendant chooses not to defend his case, and settles the dispute with his plaintiff, satisfying his claim. It is only when both parties' participation constraints are satisfied that actual litigation may occur. ${ }^{28}$

The participation constraint requires that investing in the Nash equilibrium litigation effort is at least as profitable as not investing in effort. Zero effort is possible as a corner solution to one or both parties' maximization problems eqs. (3) and (5).

The participation constraint for the plaintiff requires that $P^{*} J-X^{*}>0$. From eqs. (1) and (7), this condition can be written as

$$
\frac{1}{\theta(M, S)} \geq \alpha-1
$$

with $\theta(M, S)$ defined in eq. (2).

The participation constraint for the defendant requires that $P^{*} J+Y^{*}<J$. From eqs. (1) and (7), this condition can be written as

$$
\theta(M, S) \geq \alpha-1
$$

The plaintiff's (defendant's) participation constraint is more likely to be satisfied (violated) when $M \geq S$. For any given $\alpha$ and $M$, as $S$ decreases the plaintiff's (defendant's) participation constraint is more likely to be satisfied (violated). Moreover, for any given $\alpha$ and $S$, as $M$ increases, the plaintiff's (defendant's) participation constraint is more likely to be satisfied (violated) (Farmer and Pecorino 1999). The choice to engage in litigation depends on the effectiveness of legal expenditure, $\alpha$. As in Farmer and Pecorino (2013b), we shall analyze parties' participation constraint within three ranges of effectiveness of legal expenditures: $\alpha \leq 1,1<\alpha \leq 2$, and $\alpha>2$. This analysis allows us to identify the range of values for $\alpha, M$ and $S$ under which both parties find it optimal to enter or do not enter litigation.

For illustrative purposes, Figure 5 show the plaintiff's and the defendant's participation constraint for different values of $\alpha$, by letting $M$ and $S$ vary. The darkest area shows the combinations of $M$ and $S$ under which the plaintiff's participation constraint is satisfied (which corresponds to condition eq. (9)). The lighter area shows the combinations of $M$ and $S$ under which the defendant's participation constraint is satisfied (which corresponds to condition eq. (10)). The area of intersection (that is, the darkest area in each graph) represents the range where both participation constraints are simultaneously satisfied and litigation occurs. The area of separation (that is, the white area in Panels (e) and (f)) represents the range where both participation constraints are simultaneously violated and litigation do not occur.

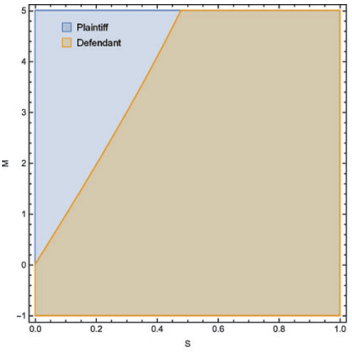

(a) $\alpha=0.5$

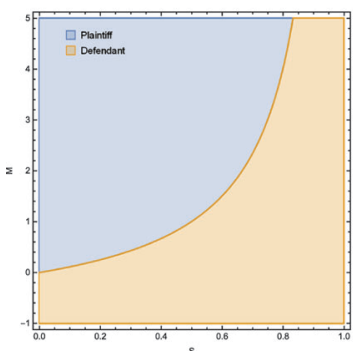

(d) $\alpha=2$

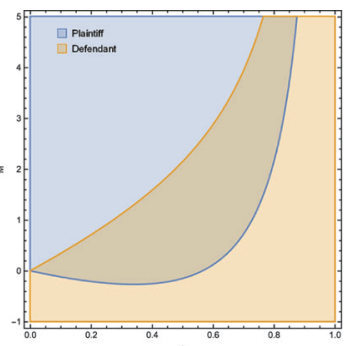

(b) $\alpha=1.1$

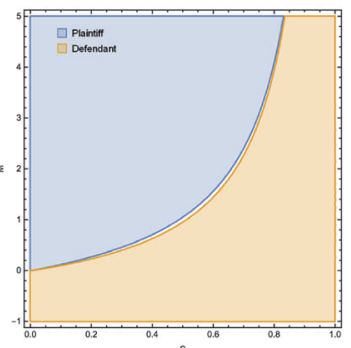

(e) $\alpha=2.1$

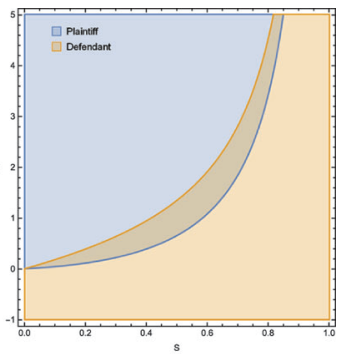

(c) $\alpha=1.5$

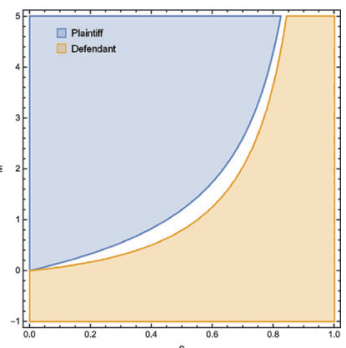

(f) $\alpha=2.5$ 
Figure 5: Litigation and No-Litigation ranges $(J=1)$.

When $\alpha \leq 1$, both parties' participation constraints are satisfied, regardless of the merit of the case and of the standard of proof (Panel (a) in Figure 5).

For $1<\alpha \leq 2$, at least one party, i.e., the party which is favored by the objective merit of the case, is willing to play the interior Nash equilibrium, and the parties' constraints are never violated simultaneously (Panels (b) and (c) in Figure 5).

For $\alpha=2$, the efforts of the parties dissipate the full value of the case. Litigation leaves no expected benefit for the parties entering litigation and no litigation should be expected. In this limiting case the parties should be indifferent between litigation and no litigation. Similarly, for $\alpha>2$, at least one party's constraint is violated (Panels (e) and (f) in Figure 5). There are cases for $\alpha>2$ in which both constraints are violated (the white areas in Panels (e) and (f) in Figure Figure 5), replicating Tullock's well-known paradox (Tullock 1980; Dari-Mattiacci and Parisi 2005). The range of these cases is narrowed when low standards of proof are applied in weakly meritorious claims and high standards of proof are applied in strongly meritorious claims.

\subsection{The Sorting Effects of Evidence Standards}

The above results allow us to evaluate the sorting effect of evidence standards. Different standards of proof affect the mix of cases that are brought to litigation, as stated in the following results.

\section{Result 2.3}

[Sorting Effect of Evidence Standards] Parties' participation constraints are more likely to be violated in low-merit (high-merit) cases when standards are set high (low).

This result follows from Result 2.1 inasmuch as higher equilibrium expenditures make litigation less appealing for one or both parties. As it will be discussed in Section 3, the results provide a valuable element for the institutional design of evidence rules. Evidence standards are not only instrumental to balance the competing goals of access to justice and judicial truth finding, but they also play a critical role in affecting parties' litigation investments and in sorting the mix of cases that will be filed and defended in court.

When $\alpha<1$, parties' participation constraints are often simultaneously satisfied, except for low-merit/highstandard and high-merit/low-standard regions, for which the plaintiff's and defendant's participation constraints are respectively violated. For $1<\alpha \leq 2$, the litigation range is wider under a preponderance standard and higher (lower) standards may discourage litigation of weakly (highly) meritorious claims.

The standard of proof influence the set of disputes settled or litigated and the resulting aggregate expenditures in litigation. ${ }^{29}$ It follows that, to discourage litigation in the presence of weakly meritorious claims it would be sufficient to require courts to use preponderance when the effectiveness of litigation expenditures is high. On the other side, to discourage litigation of strongly meritorious claims it would be sufficient to apply less demanding standards, independently from the effectiveness of litigation expenditures, hence encouraging defendants to settle meritorious claims.

These results show the effects of applying the clear and convincing evidence standard rather than the preponderance of the evidence. Clear and convincing evidence is a less commonly employed than the preponderance standard used for most civil issues, but it is often required in specific cases. For example, clear and convincing evidence is required for deportation for violation of immigration law, ${ }^{30}$ and the termination of parental rights. ${ }^{31}$ In patent law, clear and convincing evidence is required for willful infringement, ${ }^{32}$ inequitable conduct, ${ }^{33}$ correction of inventorship, ${ }^{34}$ and overcoming the presumption of priority in an interference proceeding with an issued patent. ${ }^{35}$ In these situations in which " $[\mathrm{t}]$ he interests at stake... are deemed to be more substantial than mere loss of money." footnoteAddington v. Texas, 441 U.S. at 424. See also Schwartz and Seaman (2013). a higher standard is desirable to prevent litigation on low-meritorious cases.

\subsection{Dissipation Through Litigation}

When examining the incentive and participation constraints conjunctly, it should be noted that higher equilibrium investments in litigation render litigation more costly and less appealing, thereby reducing the range of cases that are actually litigated. Higher equilibrium investments may ultimately lead to lower overall dissipation through litigation. Let us first derive the amount of total dissipation, which is given by the sum of the parties' investments weighed by the probability that they will actually engage in litigation (for a similar formulation, see e.g. Dari-Mattiacci and Parisi 2005; Luppi and Parisi 2012). Formally, this is equal to $P^{*} X^{*}+\left(1-P^{*}\right) Y^{*}$, 
where $P^{*}$ is the value of eq. (1) in equilibrium, $X^{*}$ and $Y^{*}$ are given by eq. (7). By substituting and rearranging, $P^{*} X^{*}$ can be written as follows:

$$
\frac{e^{\frac{2 M}{S}+\frac{1}{1-S}} \alpha J}{\left(e^{\frac{M}{S}}+e^{\frac{1}{1-S}}\right)^{3}}
$$

Similarly, $\left(1-P^{*}\right) Y^{*}$ can be written as follows:

$$
\frac{e^{\frac{M}{S}-\frac{1}{1-S}} \alpha J}{\left(1+e^{\frac{M}{S}-\frac{1}{1-S}}\right)^{3}}
$$

\section{Result 2.4}

[Standards of Proof and Dissipation Through Litigation] Dissipation through litigation is highest when the standard of proof and the objective merits are similar in magnitude.

Total expected expenditures in litigation, labeled as "ED" in Figure 6, are given by the sum of eqs. (11) and (12). As compared to Figure 4, Figure 6 shows that litigation expenditures peak at $J / 4$ for any given value of $M>0$.
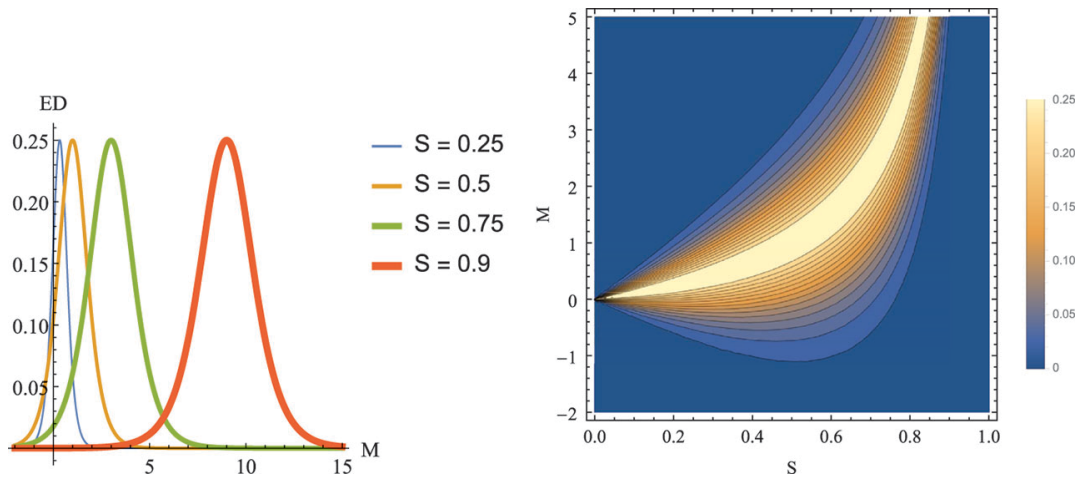

Figure 6: Dissipation through litigation $(\alpha, J=1)$.

Although Nash equilibrium aggregate efforts reach a maximum of $J / 2$, high-effort litigation in undertaken less frequently, such that dissipation remains capped and seldomly reach the values of $J / 4$. This may provide an explanation of the stylized fact that total litigation expenditures rarely reach half of the value of the case, as the standard rent-seeking model would rather predict.

\subsection{Standards of Proof and Pretrial Bargaining}

Many disputes are resolved before the beginning of an expensive legal process, in an attempt to avoid it. Some legal scholars have suggested that, in some circumstances (e.g., multiple defendants) it may be preferable to make each defendant pay plaintiff's damages discounted by the probability that the defendant in question is in fact liable, rather than litigating the case with a preponderance standard (Kaye 1982).

Much of the law and economics literature has focused on pre-trial settlement issues (e.g., Png 1983; Spier 1992, 1994b; 1997; 2002; Daughety and Reinganum 2005). In this section, we analyze parties' willingness to settle out of court. We consider the phase of bargaining prior to a fixed trial date, without the costly intervention of the court $^{36}$ : the defendant makes a settlement offer that the plaintiff can either accept (out-of-court settlement) or reject (trial stage). If the litigants cannot come to an agreement then the case goes to trial. It is shown that the interactions between the standards of proof and objectives merits affect the expectations about trial and thus the outcomes of bargains. ${ }^{37}$

\subsubsection{Preemptive Litigation Expenditures}

In the following, we extend the analysis of Hirshleifer and Osborne (2001) and Farmer and Pecorino (1999) to consider the effect of standards of proof when parties can engage in preemptive litigation. We consider a Stackelberg game, where the plaintiff (or the defendant) can commit first to a level of litigation effort $\bar{X}$ (or $\bar{Y}$ ), 
after which the defendant (or the plaintiff) responds with $\bar{Y}=\bar{Y}(\bar{X})$ (or $\bar{X}=\bar{X}(\bar{Y})$ ). The litigant with the first mover advantage can set the legal expenditures at a preemptive level. So, for example, if the plaintiff has the first mover advantage, she can set a level of spending that will induce an optimal expenditure by the defendant equal to zero. Following Farmer and Pecorino (1999), such strategy requires

$$
\frac{\bar{X}^{\alpha}}{\bar{X}^{\alpha}+\theta(M, S) \bar{Y}^{\alpha}} J-\bar{Y}=-J
$$

where $\bar{Y}=\bar{Y}(\bar{X})$ is the defendant's reaction function to the plaintiff's effort level. By moving by backward induction, the defendant's reaction function is defined by eq. (5). By substituting the defendant's reaction function into eq. (13) and solving it for $X$, the plaintiff can find the preemptive level of expenditures $\bar{X}$.

As already seen in the simpler case studied by Hirshleifer and Osborne (2001), analytical solutions are not generally obtainable in these cases and the analysis should proceed through numerical simulations. Let us assume $\alpha, J=1$. From eq. (5) we obtain

$$
\bar{Y}(\bar{X})=\sqrt{\bar{X}} e^{\frac{1}{2}\left(\frac{M}{S}-\frac{1}{1-S}\right)}-\bar{X} e^{\frac{M}{S}-\frac{1}{1-S}}
$$

By substituting $\bar{Y}(\bar{X})$ into eq. (13) and solving it for $X$, we obtain the plaintiff's preemptive level of expenditures $\bar{X}$ such that the optimal expenditure by the defendant $\bar{Y}(\bar{X})$, moving second, will be zero:

$$
\bar{X}=\theta(M, S)
$$

where $\theta(M, S)$ is defined in eq. (2). Note that eq. (15) corresponds to the left-hand side of the defendant's participation constraint in eq. (10). Similarly, if the defendant is the leader he will be able to play a preemption game against the plaintiff. Such strategy requires

$$
\frac{\bar{X}^{\alpha}}{\bar{X}^{\alpha}+\theta(M, S) \bar{Y}^{\alpha}} J-\bar{X}=0
$$

where $\bar{X}=\bar{X}(\bar{Y})$ is the plaintiff's reaction function to the defendant's effort level. Similarly to the previous case, by moving by backward induction the plaintiff's reaction function is defined by eq. (3). By substituting the plaintiff's reaction function into eq. (16) and solving it for $Y$, the defendant can find the preemptive level of expenditures $\bar{Y}$.

To obtain analytical solutions, let us assume $\alpha, J=1$. From eq. (3) we obtain

$$
\bar{X}(\bar{Y})=\sqrt{\bar{Y}} e^{\frac{1}{2}\left(\frac{1}{1-S}-\frac{M}{S}\right)}-\bar{Y} e^{\frac{1}{1-S}-\frac{M}{S}}
$$

By substituting $\bar{X}(\bar{Y})$ into eq. (16) and solving it for $Y$, we obtain the defendant's preemptive level of expenditures $\bar{Y}$ such that the optimal expenditure by the plaintiff, moving second, will be zero:

$$
\bar{Y}=\frac{1}{\theta(M, S)}
$$

with $\theta(M, S)$ defined in eq. (2). Note that eq. (18) corresponds to the left-hand side of the plaintiff's participation constraint in eq. (9). The preemptive litigation expenditures eqs. (15) and (18) are plotted in Figure Figure 7.

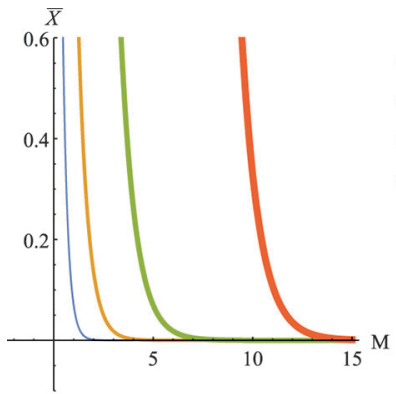

(a) Plaintiff's Preemptive Effort

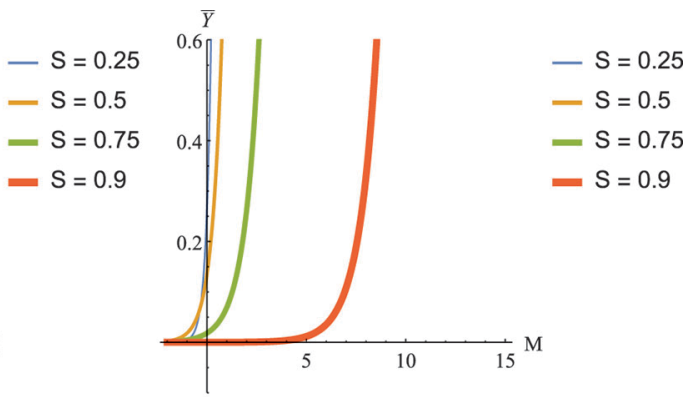

(b) Defendant's Preemptive Effort

Figure 7: Preemptive litigation expenditures of the first movers $(\alpha, J=1)$.

From eqs. (15), (18) and Figure 7, we derive the following result. 


\section{Result 2.5}

[Standards of Proof and Preemptive Litigation Expenditures]. Preemptive expenditures yield to complete dissipation (i.e., $\bar{X}=\operatorname{Jor} \bar{Y}=$ JwithJ $=1$ ) when the standard of proof is set atS $=M /(1+M)$.

Figure 7 clearly shows that plaintiffs' (defendants') preemptive litigation expenditures are decreasing (increasing) in the objective merits of the case and increasing (decreasing) in the standard of proof. The plaintiff, moving first, invests more in litigating non-meritorious cases especially in the presence of the preponderance standard, or highly meritorious cases in the presence of more demanding evidence standards. On the opposite, the defendant, moving first, will invest more in defending non-meritorious cases in the presence of a preponderance standard, and meritorious cases in the presence of more demanding evidence standards.

This result contributes to the previous literature on pre-committment in a pretrial stage and biases in litigation contexts (Wainger 1981), by showing that equilibrium outcomes are not the same under simultaneous and sequential decisions, and players gain from the opportunity to precommit themselves to a certain litigation expenditure on the basis of the standard of proof and the objective merit of the case.

\subsubsection{Contractual Choice of the Standard of Proof}

In some circumstances, parties can formally agree on the procedural rules that will be followed in the resolution of their dispute. For example, it is common for contracting parties to agree whether to have disputes resolved by arbitration or by litigation or by the court. In some jurisdictions, parties can also contractually agree on the type and amount of evidence that can be admitted in court. The contexts in which parties can vary the rules of litigation in an ex-ante contract are relatively unexplored, especially from an analytical perspective. ${ }^{38}$

Although several legal systems do not allow parties to modify the procedural rules that should be followed in the event of litigation, inasmuch as legal procedures are deemed as non-derogable and cannot be modified through contractual choice of laws, common law courts often allow parties to agree on the rules to be followed in the discovery phase of their proceedings. ${ }^{39}$ In this Section we consider the possible effect of contractual choice of evidence rules and standards of proof by parties involved in a dispute.

We will show that the specific interplay between the standard of proof and the objective merits of the case allow the agent playing as a Stackelberg leader to preempt the other player's entry in litigation.

From eq. (14), by substituting $\bar{Y}(\bar{X})$ into eq. (13) and solving for $S$, we obtain the standard of proof that the first-mover in a litigation game could commit to such that the optimal expenditure by the second-mover would be zero:

$$
\bar{S}= \begin{cases}\frac{M}{1+M} & \text { if } M \geq 0 \\ -\frac{M}{1-M} & \text { if } M<0\end{cases}
$$

Figure 8 plots the contractual choice of the standard of proof eq. (19).

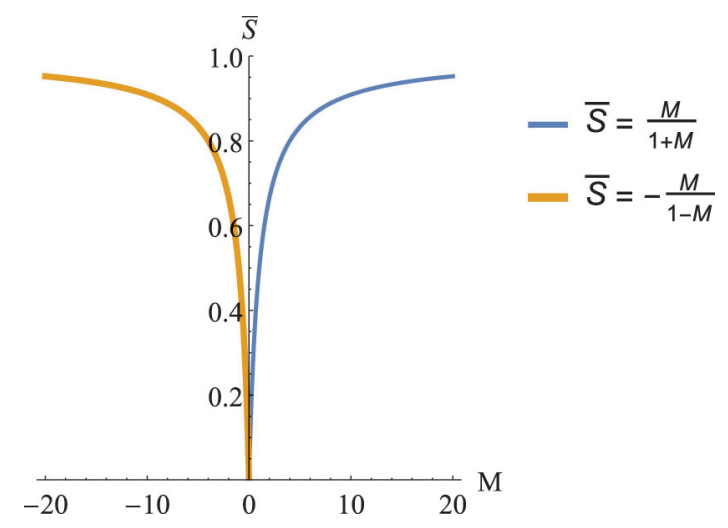

Figure 8: Contractual Choice of the Standard of Proof.

\section{Result 2.6}

[Preemptive Standard of Proof]. The party playing as a Stackelberg leader can preempt the other litigant's entry in litigation by agreeing or having the court select a standard of proof equal to $\bar{S}$ as defined in eq. (19).

The interesting result here is that a litigant may agree to a standard of proof that is prima facie disadvantageous for him, as a way to preempt the opposing party from entering litigation. This analysis is novel in the 
literature which focused exclusively on preemptive litigation expenditures, and the implications are interesting from a policy perspective especially for cases in which one party is in a better position for influencing the court's choice of evidentiary rule to be followed in their dispute. 40

Evidentiary standards can be designed to encourage parties to cooperate and thus reduce expenditures in litigation. In the previous sessions, a standard of proof set at $\bar{S}$ in eq. (19) has been shown to yield the highest equilibrium litigation expenditures (Section 2.1), as well as the complete dissipation in a pretrial stage when parties can commit to preemptive litigation expenditures (Section 2.5.1). In this Section, we argue that if parties can agree on evidence standards, litigation expenditures will be minimized.

Differently from the case of preemptive litigation expenditures, the contractual choice of the standard of proof remains at $\bar{S}$ in eq. (19) regardless of which party moves first can play as a leader. Given the lack of a firstmover advantage in this case, there is clearly scope for cooperation. With a standard set at $\bar{S}$, litigants would have an increased incentive to limit their expenditures through settlement (see Section 2.5.3). For example, a preponderance standard $S=0.5$ could effectively reduce litigation for claims that have similar objective merits. Higher or lower standards would instead facilitate settlement of strongly meritorious or frivolous claims.

\subsubsection{Split-Award Regimes}

In this section we analyze pretrial settlement agreements. Let us consider a pretrial option in which parties agree to split the asset at the pre-litigation stage. This is, for example a divorce case in which a court decides after a trial that the marital asset should be split 50/50. A settlement could achieve the same outcome, with the difference that parties would save litigation costs. The savings in the cost of a trial can make both parties better off.

Let $p r$ and $d r$ denote the plaintiff's and the defendant's reservation payoffs, respectively. Let us consider a split-asset pretrial option where $p r=\gamma_{p} J$, with $\gamma_{p} \in[0,1]$, and $d r=\gamma_{d} J$, with $\gamma_{d} \in\left[0, \gamma_{p}\right]$. The participation constraint for the plaintiff requires $P^{*} J-X^{*}>\gamma_{p} J$, whereas the participation constraint for the defendant requires $P^{*} J+Y^{*}<\left(1-\gamma_{d}\right) J$. In the benchmark case of a complete split-award, $\gamma_{d}=\gamma_{p}$. In the intermediate case with $\gamma_{d} \in\left[0, \gamma_{p}\right)$, the remaining share of the award could be lost in pre-settlement agreements or could go to the state (as it would happen under the split-awards reform when the case is settled in court; see Daughety and Reinganum 2003 and Landeo, Nikitin, and Babcock 2007).

From eqs. (1) and (7), the litigants' participation constraints can be written as ${ }^{41}$

$$
\frac{\left(1-\gamma_{p}\right)}{\theta(M, S)}-\gamma_{p}(2+\theta(M, S)) \geq \alpha-1
$$

$$
\left(1-\gamma_{d}\right) \theta(M, S)-\gamma_{d}\left(2+\frac{1}{\theta(M, S)}\right) \geq \alpha-1
$$

where $\theta(M, S)$ is defined in eq. (2). The choice to enter litigation depends not only upon the technology parameter $\alpha$, but also upon $\theta$ and the split-asset options. The litigation range (i.e., the range of values for $M, S, \alpha$ where eqs. (20) and (21) are both satisfied) is narrowed in the presence of split-asset options, as long as the technology parameter increases (see also Table 1).

If parties agree to split the entire award, either symmetrically (see the last column on the right in Table 1 , " $0.5 \mathrm{~J} \mathrm{split")} \mathrm{or} \mathrm{asymmetrically} \mathrm{(e.g.,} \mathrm{the} \mathrm{plaintiff} \mathrm{gets} 70 \%$ of the asset, whereas the defendant the $30 \%$ ), at least one of the parties' participation constraint will be violated, regardless of the values of the objective merits and standards of proof. Both parties' participation constraints will be violated when the standard of proof and the objective merit of the case are similar in magnitude (the lightest areas in the graphs in Table 1, last column on the right).

It is interesting to notice that, for $1<\alpha \leq 2$ it will be sufficient for the parties to agree on a lower split of the award than 50/50, e.g., $0.3 \mathrm{~J}$ each litigant, to avoid litigation. For example, by comparing the columns in Table 1 "no settlement" versus " $0.5 \mathrm{~J}$ split", when $\alpha=1.1$ or $\alpha=1.5$ it can be easily noticed that the litigation range under no settlement turns into a no-litigation range under a $0.3 \mathrm{~J}$ split.

When $M$ is equal or lower than zero, if the technology parameter is relatively low (i.e., $\alpha<1.5)$ the likelihood that frivolous claims will be litigated in courts decreases by setting high standards of proof or by inducing parties to agree in splitting even a relatively low share of the award (e.g., each party gets $0.3 J$ ) in a pretrial settlement.

Table 1: Pretrial negotiation: Litigation and No-litigation ranges (with $J=1$ ). 


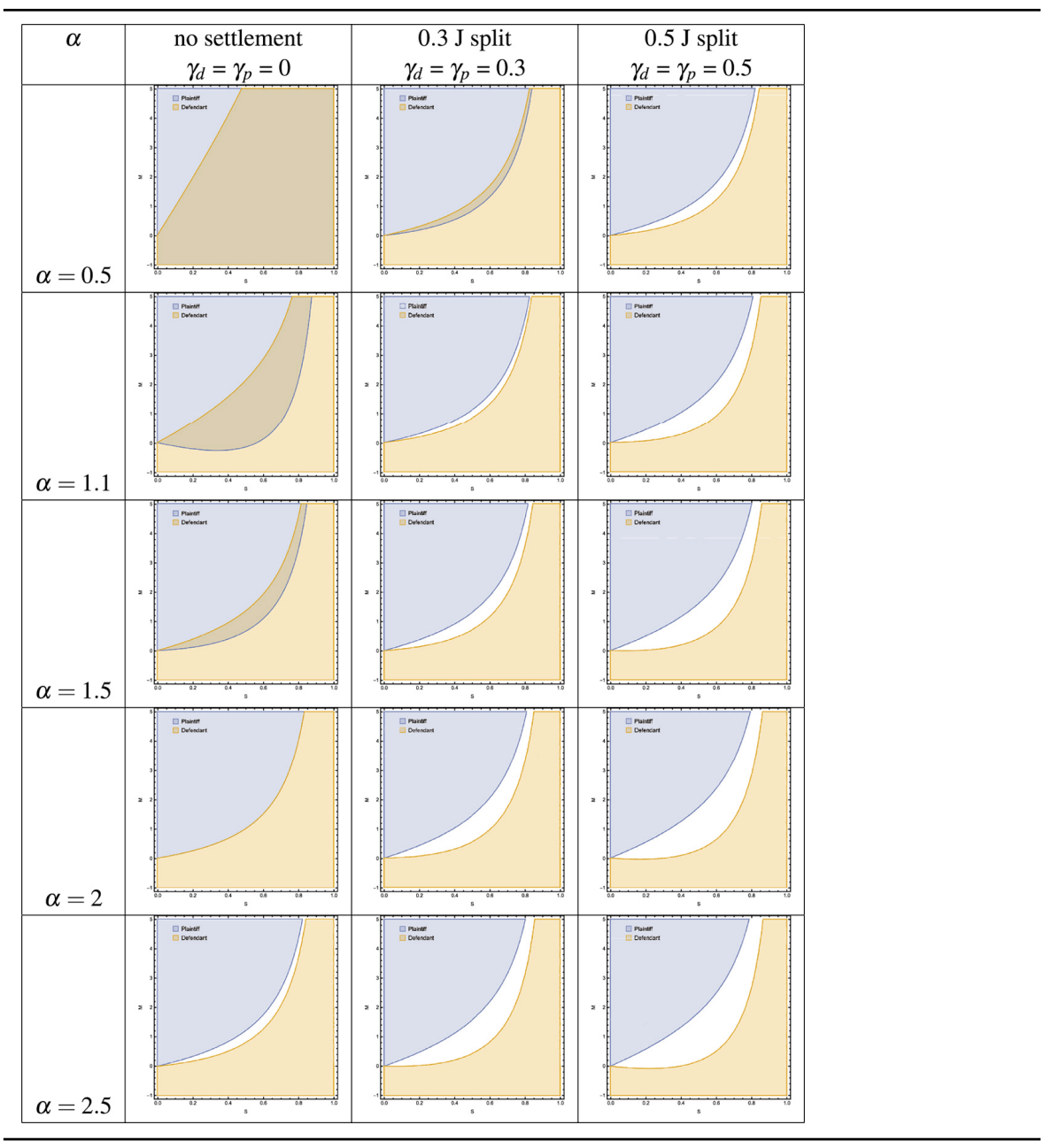

\section{Policy Implications}

In a litigated dispute parties expend resources to win or to avoid losing a case. Several contributions in the law and economics literature have framed the plaintiff's decision to file a case and the defendant's choice to defend as an endogenous decision to enter in a rent-seeking game (e.g., Katz 1988; Hirshleifer 1989; Farmer and Pecorino 1999; Luppi and Parisi 2012; De Mot 2013). Existing litigation models assume that the relative success in a lawsuit depends upon two main factors: the merits of a party's claim and the parties' litigation efforts. By focusing attention on these two elements, litigation scholars abstracted away from other policy and institutional variables, such as the standard of proof and its relation with the other factors that affect the outcome of a case.

In a typical lawsuit, the judge assesses the credibility and the strength of the evidence presented by the parties in light of the applicable standards of proof. In this paper, we extend the traditional litigation model to analyze the effects of alternative standards of proof on the parties' litigation choices. We show that parties' litigation choices are sensitive to the interrelation between the objective merit of the case and the standard of proof adopted by the court. Standards of proof play three crucial roles in civil litigation: standards serve as devices for (i) taming parties' investments in litigation, (ii) for sorting the cases brought to courts, (iii) for preempting litigation and encouraging settlement options out of court.

These results provide valuable insights for the institutional design of evidence rules. Firstly, an inverse relationship between the standard of proof and the objective merit of the case in warranted to sort the mix of cases brought to courts and, eventually, to mitigate parties' expenditures in litigation. A proportional relationship between the standard of proof and the objective merit of the case in warranted to reduce litigation and foster the case resolution out of court. When parties' participation in litigation is to be expected (i.e. for lower values of $\alpha$, as it is likely in private litigation), highly meritorious cases brought by plaintiffs might be adjudicated with lower standards of proof, to avoid an escalation in the parties' litigation investments. Similarly, evidence rules such as legal presumptions and res ipsa cases can be viewed as situations where the legal system lowers the standard of proof when plaintiffs bring a strong case, avoiding unnecessary investments in discovery and 
litigation. In these cases, lower standards allow the delivery of judicial outcomes at a lower cost in terms of litigation expenditures and judicial errors. For cases characterized by balanced merits, highest expenditures are observed under the preponderance of evidence standard, $S=.5$. Raising the standard of proof for less meritorious cases would reduce aggregate expenditures. Plaintiffs with low-merit claims that are faced with a higher standard of proof would see their claims harder to win, and will be less likely to pursue it. From a policy standpoint, this outcome would also have some appeal, inasmuch as an increase in the standard of proof would keep a larger number of non-meritorious claims out of the court system. As a result, more meritorious cases would be pursued with lower expenditures and less meritorious cases would be filed less frequently.

In situations where the parties' participation in litigation is not guaranteed (i.e., for higher values of $\alpha$, such as in high scale corporate litigation with increasing returns to effort), the policy corollaries are somewhat different. Evidence rules that lead to higher equilibrium investments may ultimately make litigation less appealing and discourage participation in litigation. Lowering the standards of evidence for meritorious claims may thus foster access to justice in these situations.

These policy considerations will ultimately raise the question of whether tailored standards of proof might have undesirable distributive effects that conflict with principle of justice. A brief consideration of this question is thus in order here. Changing standards of proof affects the parties' expected payoffs, but in many legal situations involving voluntary relationships, such as contract or business law, such distributive effects will generally be captured and corrected by the price system. A prospective plaintiff would account for the financial impact of a higher standard of proof when entering into a contractual or business relationship. Both parties would then prefer an evidence regime that lowers their expected litigation costs, if a dispute ever arises. After correcting the distributive effect, tailored standards of proof would hence satisfy the Pareto test when applied to contractual and business settings. In these situations, tailoring standards of proof to tame excessive dissipation of resources through litigation can be viewed as desirable for all parties involved. In other civil settings, however, the parties do not have an opportunity to adjust the distributive effects of standards of proof through the price system. In a tort setting, for example, plaintiff and defendant do not know each other before the accident and cannot correct the financial effects of tailored standards of proof through a price adjustment. Tailored standards would thus only satisfy a Kaldor-Hicks potential compensation test. From a normative standpoint, a word of caution would therefore be necessary when considering tailored standards of proof in involuntary legal relationships, inasmuch as the distributive effects of legal standards could not be corrected through the price system.

As a final observation, although our analysis focuses exclusively on civil litigation, our results could be easily recast to consider criminal adjudication. The potential application of our results in the field of criminal adjudication, however, requires some disclaimers. Unlike civil litigation, criminal justice involves additional social values that may outweigh the goal of minimization of legal expenditures. Undoubtedly, our results are in line with Blackstonian principles: raising the standard of proof for weak prosecution cases may be an appealing way to further reduce the risk of false convictions; likewise, lowering the standard of proof for strong prosecution cases may reduce the risk of false acquittals. But there are too many other values that affect the balance of criminal adjudication for us to suggest at this point that our results should play a role in the criminal justice system. We shall leave these normative questions for others to explore.

\section{Concluding Remarks}

Future analysis should extend our results to consider other important issues on standards of proof applied to civil litigation. The first natural next step would be to extend our analysis to alternative fee-shifting regimes, comparing the English rule and the American rule for allocating legal costs (Spier 1994a, 1997). It has been argued that use of English loser-pays rule will discourage frivolous suits and may therefore reduce total litigation costs. At the same time, however, it has been proved that the use of the English rule will raise spending on cases that proceed to trial. The question arising here is whether there exists an optimal combination of standards of proof and the allocation of lawyer fees at trials such that the expected aggregate litigation costs are minimized.

Further extensions should consider the courts' competing objectives of avoiding judicial errors and providing deterrence (Demougin and Fluet 2005). One direction for future research would be to incorporate these considerations into our simple framework to analyze parties' incentives under alternative evidence standards. In addition, our setup can be extended to analyze potential reasons for the divergence between private and social motives to settle lawsuits (Shavell 1997; Spier 1997), including asymmetric information between the litigants during settlement negotiations, and discuss how different evidentiary standards can mitigate such discrepancy. Related to this latter point, it could be interesting to analyze whether alternative standards of proof can help encourage (or discourage) litigation when there are too few (or too many) cases that reach litigation, compared to the social optimum. 


\section{Acknowledgements}

The authors would like to thank Luna Bellani, Frank Bohn, Ben Johnson, Rainer Kotshy, Arye Hillman, Henrik Lando, Tore Nilssen and Heinrich Ursprung for helpful comments and constructive criticism, as well as the other participants at the 24th Workshop on Political Economy (Silvaplana, 2015), the 33rd Annual Meeting of the European Association of Law and Economics (University of Bologna, 2016), the 27th Annual Meeting of the American Law and Economics Association (Yale University, Law School, 2017), the 4th International Meeting in Law and Economics (ERUDITE-Université Paris Est-Créteil, 2017). The authors are extremely grateful to Tapas Kundu, for his helpful comments and suggestions.

\section{Notes}

1 Following Tullock $(1967,1980)$, contest models have been used to analyze competition in a wide variety of contexts. See, among others, Congleton, Hillman, and Konrad (1980, 2008a, and 2008a) , and Congleton and Hillman (2015).

2 Closely related to this paper, Katz (1988) and Farmer and Pecorino (1999) analyzed parties' success probabilities as functions of effort and merits of a case. Interestingly, Katz (1988) claimed that " $M$ [the merits of a case] can be interpreted as measuring the standard of proof." This paper will show that this equivalence does not always hold, and that the interaction between evidence standards and objective merits play a crucial role in litigation contexts. Hirshleifer and Osborne (2001) further extended this analysis by including a force exponent weighting the relative importance of effort versus fault in determining the litigation outcome. In Hirshleifer and Osborne's (2001) analysis, standards of proof are considered as bias in favor of defendants or plaintiffs, which can be introduced as an extension to their analytical framework.

3 The standard of proof is the degree of certainty required for a jury or judge to find for a party on an issue, and should be distinguished from the broader concept of the burden of proof. The burden of proof can be meant as burden of production --which identifies which party must offer evidence in order to raise an issue in litigation; as burden of persuasion -which identifies the party who must persuade the jury in its favor to prevail; and as standard of proof. On this distinction, see among others Schwartz and Seaman (2013). See also Clermont and Sherwin (2002) and Clermont $(2004,2008)$.

4 For an extensive discussion on the "preponderance of evidence" standard, see Devitt, Blackmar, and Wolff (1987) and Dennis (1999), 362-367 and Porat and Stein (2001, 16-56). See also Keenan and Rubin (1982) and Demougin and Fluet (2005, 2006) , and Zamir and Ritov (2012).

5 On the standards for preliminary injunctions, see, among others, Leubsdorf (1978). Another example can be found in Italian business law, where fast-track summary proceedings, with a lower standard of proof, are granted for settling debt-related litigations when debt is certain and undisputed (i.e. for a high merit case). A creditor may apply for a payment decree (decreto ingiuntivo under Law no. 69/2009) provided that the creditor proves that the debt is certain and undisputed. When an injuction proceeding is adopted, the standard of proof is very limited.

6 Most common-law countries consider mere preponderance as not sufficient in specific judicial cases of particular gravity for the defendant as for example denaturalization (Nishikawa v. Dulles, 356 U.S. 129, 1958), deportation (Woodby v. Immigration and Naturalization Service, 385 U.S. 276, 1966), civil commitment (Addington v. Texas, 441 U.S. 418, 1979), and termination of parental rights (Santosky v. Kramer, 455 U.S. $745,1982$.$) .$

T 7 In such cases, the intermediate standard of "clear and convincing evidence" must be met. This standard, often grouped under the banner of clear and convincing evidence, roughly translate as much-more-likely-than-not. The degree of certainty required by the clear and convincing standard has been estimated to range from $67 \%$ to $75 \%$ (United States v. Fatico, 1978; McCauliff 1982).

8 While civil-law courts do not differentiate between civil and criminal cases with regard to the standard of proof, common-law courts generally apply different standards of proof depending upon the type of the case. See, e.g., Addington v. Texas 441 U.S. 418, 422-25 (1979), discussing the three commonly applied standards of proof in American law. In common-law criminal law, the charge must be established "beyond a reasonable doubt," which means proof to a virtual certainty. This standard is at the top end of the probability scale and has been estimated by judges to range from 90\% to 95\% (United States v. Fatico, 458 F Supp. 388, E.D.N.Y. 1978; see, e.g., Kagehiro and Stanton (1985) and the references therein). In common-law civil law, the plaintiff wins if only "preponderance of evidence" (or "balance of probabilities") is in her favor. See also Horowitz and Kirkpatrick (1996).

9 Intime Conviction is a French term that means reasonable conviction, reasonable certainty, state of being satisfied beyond reasonable doubt (personally convinced), personal conviction of the court (after considering all the evidence). It is also referred in the literature as standard of "full conviction." See Taruffo (2003) and Engel (2008). The standard of proof in Germany is better described as a conviction raisonnée rather than the French intime conviction (Kaye 1983). See French Code de Procédure Pénale, Art. 3531; German Zivilprozessordnung,§ 286 I 1; German Strafprozessordnung, § 261.

10 See, e.g, for German law BGH NJW 1995, 2169; NJW 2004, 777; for Swiss law BGE 130 III 321 sect. 3.3; 132 III 715 sect. 3.2.

11 Kaye (1983) showed that judges in Switzerland --a civil-law country-- are prone to use a much lower decision threshold in civil cases than required by legal doctrine and case law. The actual difference in standards of proof in civil cases between Common Law and Civil Law may therefore be much smaller than expected.

12 Addington v. Texas, 441 U.S. 418 (1979); Santosky v. Kramer, 455 U.S. 745 (1982); Grogan v. Garner, 498 U.S. 279 , 286 (1991). See the seminal papers by Kaplan (1968) and Cullison (1969). See also Kaye $(1983,1987)$.

13 By contrast, in criminal cases the cost of Type-I and Type-II errors (i.e., erroneously ruling against the defendant and against the plaintiff, respectively) is assumed as asymmetric (Kaplan 1968; Cullison 1969). The false conviction of an innocent individual is generally perceived to be much more undesirable than the false acquittal of a guilty criminal (e.g., Speiser v. Randall, 357 U.S. 513, 1958; In re Winship, 397 U.S. $358,1970)$. Hence, in civil cases the expected cost of legal errors can simply be minimized by minimizing the frequency of errors. Standards of proof are consequently set in favor of criminal defendants to reduce the expected cost of adjudication errors. See Brook (1982), Clermont (2004) and the references therein.

14 For a comparative legal analysis of standards of proof see, among others, Clermont and Sherwin (2002); Clermont (2004 and 2008). 15 On this point, see also (Demougin and Fluet 2005).

1635 U.S.C. $\S 282$ (2006 \& Supp. V 2012) ("A patent shall be presumed valid... The burden of establishing invalidity of a patent or any claim thereof shall rest on the party asserting such invalidity."). 
17 See also Guerra, Luppi, and Parisi (2018), analyzing the optimal standard of proof as a function of jury size and voting rule. 18 Although our analysis applies to civil litigation, the results can be potentially applied also to criminal adjudication with some caution. Please refer to Section 3 for a brief discussion on this point. On the optimal standards of proof in criminal adjudications, see, among others, Yilankaya (2002) and Guerra, Luppi, and Parisi (2018). This paper shows that determining the standard of proof requires considerations of the objective merit of the plaintiff's claim, instead of merely apply fixed thresholds.

19 For an extensive review of possible standards of proof, we refer the reader to Section 1.

20 Our framework follows the well-known Tullock rent-seeking game, where $0<\alpha \leq 1$ ensures concavity and thus, converge to the global maximum. As in Farmer and Pecorino (1999), in our setup $\alpha$ can also take values above 1 to analyze corner solutions, in which one or both players prefers spending zero effort rather than the Nash equilibrium. Indeed, when $\alpha>1$, the solution in eq. (7) may not constitute an equilibrium since one or both players' participation constraint is likely to be violated, as we show in Section 2.2.

21 See also Froeb, Ganglmair, and Tschantz (2016) assuming that the court decides in favor of the party with the most credible explanation (a "theory of the case") given the discovered evidence. With a "noisy" court, litigants face a trade-off between making more favorable claims (e.g., the plaintiff will claim higher damages) and the likelihood or credibility of that claim (e.g., high claimed damages might not be supported by evidence). A special case of the probability of winning is the linear Tullock lottery, and, depending on the variance of the noise, a number of other special cases are considered. The results show that adversarial decision-making (where disputants present to the court explanations of the data) can result in a biased decision relative to an inquisitorial benchmark. A similar approach has been also used by Deffains, Demougin, and Desrieux (2017).

22 To see the similarities between our approach and Farmer and Pecorino's (1999) litigation success function, one might rearrange eq. (1) as $P=\frac{e^{\frac{M}{S}} X^{\alpha}}{e^{\frac{M}{S}} X^{\alpha}+e^{\frac{1}{1-S}} \gamma^{\alpha}}$. The function $\theta$ captures the effect of $M$ and $S$ on the parties' return to effort and has the main advantage of making our framework more general and easily adaptable to other contexts. Indeed, the findings of our analysis hold true for other general specifications of $\theta$ that satisfy $\partial \theta(M, S) / \partial M<0$ and $\partial \theta(M, S) / \partial S<0$.

23 This is intuitive and consistent with prior contributions on standards of proof. See, among others, McNaughton (1955) and Redmayne (1999).

24 By following Farmer and Pecorino's (1999) contest function, our specification can be both easily compared to the conventional results in the rent-seeking literature, and also adapted to other frameworks, such as the one used by Deffains, Demougin, and Desrieux (2017).

25 This result is coherent with the existing literature on evidence standards. As the threshold of the evidence standard increases, the likelihood of erroneously ruling against the defendant (Type-I error) decreases whereas the likelihood of erroneously ruling against the plaintiff (Type-II error) increases. Thus, a more demanding threshold would be particularly preferable to minimize the occurrence of Type-I errors. A formal analysis on the interrelation between standards of proof and judicial errors lies beyond the scope of this paper. For a more extended discussion on the topic, see Davis (1994), Demougin and Fluet (2005), and Guerra, Luppi, and Parisi (2018), and the references therein.

26 These results are interesting when compared to other asymmetries in litigation contests. Dari-Mattiacci et al. (2015) showed that asymmetries in parties' payoffs and efforts may arise in the presence of asymmetries in marginal returns to effort, valuations of the rent, and bargaining power.

27 Microsoft Corp. v. i4i Ltd. P'ship, 131 S. Ct. 2238 (2011).

28 Without loss of generality, we are here assuming that parties do not engage in extra-judicial settlement negotiations. Pretrial bargains are considered in Section 2.5 .

29 A standard of proof slightly higher than preponderance involves only second-order effect on deterrence, while it has first-order effects on the probability of winning the suit (Demougin and Fluet 2006).

30 Woodby v. INS, 385 U.S. 276, 286 (1966).

31 Santosky v. Kramer, 455 U.S. 745, 747-48 (1982).

32 In re Seagate Tech., LLC, 497 F.3d 1360, 1371 (Fed. Cir. 2007) (en banc).

33 Therasense, Inc. v. Becton, Dickinson \& Co., 649 F.3d 1276, 1287 (Fed. Cir. 2011) (en banc).

ت 34 Hess v. Advanced Cardiovascular Sys., Inc., 106 F.3d 976, 980 (Fed. Cir. 1997).

35 Price v. Symsek, 988 F.2d 1187, 1191 (Fed. Cir. 1993).

36 Bargaining can occur at any time in the legal process, even after a trial has begun and also while the jury is deliberating. In this paper we specifically focus on out-of-court settlement.

37 Since deterrent effects of settlements and trials lies outside the scope of our analysis, in the following we will assume that the suit has a positive expected value from the perspective of the plaintiff. As we will discuss in Section 4, the analysis on the deterrent effects of alternative standards of proof could be an interesting extension of our study. On the deterrent effects of settlements and trials, see, among others, Polinsky and Rubinfeld (1988) and Shavell (1997).

38 For an extensive legal discussion on this topic, see Scott and Triantis (2006).

39 Common law courts generally honor the (reasonable) contractual provisions on the standard of proof as well as on the burden of production. As pointed out by Scott and Triantis (2006), many contracts contain this kind of provisions. For example, it is common for parties in indemnity agreements to reallocate burdens and elevate standards of proof. Consider, among others, the standard indemnification agreement between DAOU Systems with its directors and officers, where the standard of proof is commonly raised from the default preponderance standard to clear and convincing evidence).

40 For example, in patent law, the burden of establishing invalidity of a patent or any claim thereof shall rest on the party asserting such invalidity (Schwartz and Seaman 2013). In the Microsoft Corp. v. i4i Ltd. P'ship case, Microsoft argued that it should be required to prove invalidity of a patent by only a preponderance of the evidence. However, the district court judge ruled that Microsoft had to prove invalidity by clear and convincing evidence, and denied Microsoft's request for an alternative instruction.

41 It is worth noting that in the no-settlement case $\gamma_{d}=\gamma_{p}=0$, eqs. (20) and (21) reconciles with eqs. (9) and (10), respectively.

\section{References}

Brook, J. 1982. “Inevitable Errors: The Preponderance of the Evidence Standard in Civil Litigation.” Tulsa Law Journal 18: 79.

Clermont, K. M. 2004. "Standards of Proof in Japan and the United States." Cornell International Law Journal 37: 263.

Clermont, K. M. 2008. “Standards of Proof Revisited." Vermont Law Review 33: 469.

Clermont, K. M., and Sherwin E.. 2002. "A Comparative View of Standards of Proof." American Journal of Comparative Law 243-275.. 
Congleton, R. D., and Hillman A.. 2015. A Companion to Rent Seeking: Theory and Practice. Cheltenham, UK: Edward Elgar.

Congleton, R. D., Hillman A. L., and Konrad K. A.. 1980. "Forty Years of Research on Rent Seeking: An Overview." In 40 Years of Research on Rent Seeking, Volume 1: Theory of Rent Seeking, edited by Congleton R. D., Hillman A. L., and Konrad K. A.. Heidelberg: Springer.

Congleton, R. D., Hillman A. L., and Konrad K. A.. 2008a. 40 Years of Research on Rent Seeking, Volume 1: Theory of Rent Seeking. Heidelberg: Springer.

Congleton, R. D., Hillman A. L., and Konrad K. A.. 2008b. 40 Years of Research on Rent Seeking, Volume 2: Rent Seeking in Practice. Heidelberg: Springer.

Cooter, R., and Emons W.. 2003. "Truth-Revealing Mechanisms for Courts." Journal of Institutional and Theoretical Economics JITE 159 (2): 259279.

Cullison, A. D. 1969. "Probability Analysis of Judicial Fact-finding: A Preliminary Outline of the Subjective Approach. "University of Toledo Law Review 1: 538.

Dari-Mattiacci, G., Langlais E., Lovat B., and Parisi F.. 2015. “Asymmetries in Rent Seeking.” In Companion to the Political Economy of Rent Seeking, edited by Congleton R. D., and Hillman A. L..

Dari-Mattiacci, G., and Parisi F. 2005. “Rents, Dissipation and Lost Treasures: Rethinking Tullock's Paradox." Public Choice 124 (3-4): 411-422.

Daughety, A. F., and Reinganum J. F.. 2003. “Found Money? Split-Award Statutes and Settlement of Punitive Damages Cases.” American Law and Economics Review 5 (1): 134-164.

Daughety, A. F., and Reinganum J. F.. 2005. “Economic Theories of Settlement Bargaining." Annual Review of Law and Social Sciences 1: 35-59.

Davis, M. L. 1994. "The Value of Truth and the Optimal Standard of Proof in Legal Disputes." Journal of Law, Economics and Organization 10: 343.

De Mot, J. 2013. "Comparative versus Contributory Negligence: A Comparison of the Litigation Expenditures." International Review of Law and Economics 33: 54-61.

Deffains, B., Demougin D., and Desrieux C.. 2017. “Choosing adr or Litigation." International Review of Law and Economics 49: 33-40.

Demougin, D., and Fluet C.. 2005. “Deterrence versus Judicial Error: A Comparative View of Standards of Proof." Journal of Institutional and Theoretical Economics JITE 161 (2): 193-206.

Demougin, D., and Fluet C.. 2006. “Preponderance of Evidence.” European Economic Review 50 (4): 963-976.

Dennis, I. H. 1999. The Law of Evidence, Volume 604. London: Sweet and Maxwell London.

Devitt, E. J., Blackmar C. B., and Wolff M. A.. 1987. Federal Jury Practice and Instructions, Volume 1. West Pub. Co.

Engel, C. 2008. "Preponderance of the Evidence versus Intime Conviction: A Behavior Perspective on a Conflict between American and Continental European Law." Vanderbilt Law Review 33: 435.

Farmer, A., and Pecorino P.. 1999. "Legal Expenditure as a Rent-Seeking Game." Public Choice 100 (3-4): 271-288.

Farmer, A., and Pecorino P.. 2013a. "Discovery and Disclosure with Asymmetric Information and Endogenous Expenditure at Trial." Journal of Legal Studies 42 (1): 223-247..

Farmer, A., and Pecorino P.. 2013b. “Litigation with a Variable Cost of Trial." Review of Law and Economics.

Froeb, L. M., GangImair B., and Tschantz S.. 2016. “Adversarial Decision-making: Choosing between Models Constructed by Interested Parties." Journal of Law and Economics 59. forthcoming..

Gradstein, M. 1995. "Intensity of Competition, Entry and Entry Deterrence in rent Seeking Contests." Economics and Politics 7 (1): $79-91$.

Guerra, A., Luppi B., and Parisi F.. 2018. “Designing Optimal Juries.” Unpublished Manuscript. Available at SSRN: http://dx.doi.org/10.2139/ssrn.2973943.

Hay, B. 1997. "Allocating the Burden of Proof." Indiana Law Journal 72: 651-679.

Hay, B. L., and Spier K. E.. 1997. "Burdens of Proof in Civil Litigation: An Economic Perspective." Journal of Legal Studies 26: 413-431.

Hillman, A. L., and Katz E.. 1988. "Risk-averse Rent Seekers and the Social Cost of Monopoly Power." In The Political Economy of Rent-Seeking, edited by Rowley C. K., Tollison R. D., and Tullock G., 81-90. Springer..

Hirshleifer, J. 1989. Conflict and Rent-Seeking Success Functions: Ratio vs. Difference Models of Relative Success." Public Choice 63 (2): $101-112$. Hirshleifer, J., and Osborne E.. 2001. “Truth, Effort, and the Legal Battle." Public Choice 108 (1-2): 169-195.

Horowitz, I. A., and Kirkpatrick L. C.. 1996. "A Concept in Search of a Definition: The Effects of Reasonable Doubt Instructions on Certainty of Guilt Standards and Jury Verdicts." Law and Human Behavior 20 (6): 655.

Kagehiro, D. K., and Stanton W. C.. 1985. "Legal vs. Quantified Definitions of Standards of Proof." Law and Human Behavior 9 (2): 159.

Kaplan, J. 1968. “Decision Theory and the Factfinding Process." Stanford Law Review: 1065-1092..

Kaplow, L. 2012. "Burden of Proof." The Yale Law Journal: 738-859..

Katz, A. 1988. Judicial Decisionmaking and Litigation Expenditure. International Review of Law and Economics 8 (2): 127-143.

Kaye, D. 1982. "The Limits of the Preponderance of the Evidence Standard: Justifiably Naked Statistical Evidence and Multiple Causation." Law and Social Inquiry 7 (2): 487-516.

Kaye, D. H. 1983. "Statistical Significance and the Burden of Persuasion." Law and Contemporary Problems 46 (4): 13-23.

Kaye, D. H. 1987. "Apples and Oranges: Confidence Coefficients and the Burden of Persuasion." Cornell Law Review 73: 54.

Keenan, D. C., and Rubin P. H.. 1982. “Criminal Violations and Civil Violations." Journal of Legal Studies 11 (2): 365-377.

Krueger, A. O. 1974. "The Political Economy of the Rent-Seeking Society." American Economic Review: 291-303.

Landeo, C. M., Nikitin M., and Babcock L.. 2007. "Split-Awards and Disputes: An Experimental Study of a Strategic Model of Litigation." Journal of Economic Behavior and Organization 63 (3): 553-572.

Lemley, M. A., and Shapiro C.. 2005. “Probabilistic Patents." The Journal of Economic Perspectives 19 (2): 75-98.

Leubsdorf, J. 1978. "The Standard for Preliminary Injunctions." Harvard Law Review: 525-566.

Lichtman, D., and Lemley M. A.. 2007. "Rethinking Patent Law's Presumption of Validity." Stanford Law Review: 45-72.

Luppi, B., and Parisi F.. 2012. "Litigation and Legal Evolution: Does Procedure matter?" Public Choice 152 (1-2): 181-201.

McCauliff, C. M. 1982. "Burdens of Proof: Degrees of Belief, Quanta of Evidence, or Constitutional Quarantees." Vanderbilt Law Review $35: 1293$.

McNaughton, J. T. 1955. "Burden of Production of Evidence: A Function of a Burden of Persuasion." Harvard Law Review 68 (8): $1382-1391$.

Miceli, T. J. 1990. “Optimal Prosecution of Defendants Whose Guilt is Uncertain." Journal of Law, Economics, and Organization 6: 189. 
Parisi, F. 2002. "Rent-Seeking Through Litigation: Adversarial and Inquisitorial Systems Compared." International Review of Law and Economics 22 (2): 193-216.

P’ng, I. P. 1983. "Strategic Behavior in Suit, Settlement, and Trial." The Bell Journal of Economics: 539-550.

Polinsky, A. M., and Rubinfeld D. L.. 1988. “The Deterrent Effects of Settlements and Trials." International Review of Law and Economics 8 (1): 109-116.

Porat, A., and Stein A.. 2001. Tort Liability Under Uncertainty. Oxford, UK: Oxford University Press.

Redmayne, M. 1999. "Standards of Proof in Civil Litigation." The Modern Law Review 62 (2): 167-195.

Rubinfeld, D. L., and Sappington D. E.. 1987. "Efficient Awards and Standards of Proof in Judicial Proceedings." The RAND Journal of Economics: 308-315.

Sanchirico, C. W. 1997. "The Burden of Proof in Civil Litigation: A Simple Model of Mechanism Design." International Review of Law and Economics 17: 431-477.

Schwartz, D. L., and Seaman C. B.. 2013. "Standards of Proof in Civil Litigation: An Experiment from Patent Law." Harvard Journal of Law and Technology 26.

Scott, R. E., and Triantis C. C.. 2006. “Anticipating Litigation in Contract Design.” The Yale Law Journal 115 (4): 814-879.

Shavell, S. 1997. "The Fundamental Divergence between the Private and the Social Motive to Use the Legal System." Journal of Legal Studies 26 (S2): 575-612.

Spier, K. E. 1992. “The Dynamics of Pretrial Negotiation." The Review of Economic Studies 59 (1): 93-108.

Spier, K. E. 1994a. “Pretrial Bargaining and the Design of Fee-Shifting Rules.” The RAND Journal of Economics: 197-214.

Spier, K. E. 1994b. "Settlement Bargaining and the Design of Damage Awards." Journal of Law, Economics, and Organization: 84-95.

Spier, K. E. 1997. "A Note on the Divergence between the Private and the Social Motive to Settle Under a Negligence Rule. Journal of Legal Studies 26 (S2): 613-621.

Spier, K. E. (2002. "Settlement With Multiple Plaintiffs: The Role of Insolvency." Journal of Law, Economics and Organization 18 (2): 295 -323.

Taruffo, M. 2003. "Rethinking the Standards of Proof." American Journal of Comparative Law 51 (3): 659-677.

Tullock, G. 1967. "The Welfare Costs of Tariffs, Monopolies, and Theft." Western Economic Journal 5 (3): 224-32.

Tullock, G. 1975. “On the Efficient Organization of Trials.” Kyklos 28 (4): 745-762.

Tullock, G. 1980. “Efficient Rent-Seeking. In Toward a Theory of the Rent-Seeking Society, edited by Buchanan J. M., Tollison R. D., and Tullock C., 97-112. College Station, TX: Texas A \& M University Press.

Wainger, R. A. 1981. “Santosky v. Kramer: Clear and Convincing Evidence in Actions to Terminate Parental Rights.” University of Miami Law Review 36: 369.

Yilankaya, O. 2002. "A Model of Evidence Production and Optimal Standard of Proof and Penalty in Criminal Trials." Canadian Journal of Economics/Revue Canadienne D'economique 35 (2): 385-409.

Zamir, E. and Ritov I. 2012. “Loss Aversion, Omission Bias, and the Burden of Proof in Civil Litigation." Journal of Legal Studies 41 (1): $165-207$. 
Reproduced with permission of copyright owner. Further reproduction prohibited without permission. 